Jasmina POPOVSKA

UDK:17.022.0:14

Original research paper

Prudentia and natural law: St. Thomas Aquinas

Abstract

The amalgamation of the two traditions of thought, the Aristotelian and the Christian, in the ethics of St. Thomas Aquinas was also reflected in the development of the concept prudentia. Prudentia in Aquinas' philosophy is directly modeled on Aristotle's $\varphi \rho o$ vi $\eta \iota \varsigma$, but converges in the theological characteristics that he attributes to this concept: the relation of prudentia and the theological virtues given by God's grace, the relation between prudentia and divine providentia, the relation of prudentia with charity, and the most significant characteristics - the introduction of natural law and synderesis - the innate human ability to recognize the eternal first principles of moral reasoning.

This article follows through the main aspects of this concept in the philosophy of St. Thomas Aquinas and problematizes the novelties he introduces. The main component that allows Aquinas to overcome the great problems that arise in defining prudentia is the addition of natural law. With this intervention by Aquinas, the flexibility of Aristotle's ethics has been replaced by more certain principles that determine moral actions. But the question remains how valuable it is to sacrifice freedom at the expense of certainty in moral deliberation and action.

Key words: Aquinas, $\varphi \rho o ́ v \eta \sigma \iota s$, prudentia, natural law, synderesis

Following the characteristics of his philosophy in general, St. Thomas Aquinas' moral theory represents an amalgam of two seemingly disparate traditions: Aristotle's philosophy and Christian theology. On the one hand, he accepts Aristotle's tendency to evaluate an action according to whether or not it contributes to the attainment of the ultimate end of life - $\varepsilon \dot{v} \delta \alpha \mu \mu$ ví $\alpha$. On the other, he believes that achieving complete $\varepsilon \dot{v} \delta \alpha \mu$ oví $\alpha$ in this life is impossible and that it consists in bliss, or in establishing communion with God in the next life. In that sense, attaining such a state, which exceeds our human capacities, is impossible if there is no Divine intervention in order to re-establish the good in us and to conform us to His will. These premises of both intellectual backgrounds present a special challenge for Aquinas: to remain close to Aristotle in the description of human action and at the same time close to Augustine in the need for conforming to the eternal law. Through a broad and comprehensive approach, a characteristic of his philosophical system, Aquinas addresses the most important issues that affect moral life as a whole: the nature of human action, virtues, natural law, and the ultimate end of man. In such discussions, 


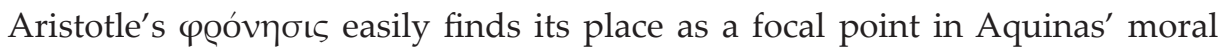
theory as prudentia.

Aquinas makes a detailed analysis of the nature of prudentia as a virtue when dealing with topics elaborated in questions 47-56 in secunda secundae pars of his Summa Theologiae (ST II-II), and most often this is the general place to refer to when it comes to this virtue. But in a broader context, Aquinas deals with prudentia in some of the previous chapters. The first references and definitions of prudentia are found much earlier in his system exhibited in Summa, where issues that have a more general theme are addressed. This also seems natural, given Summa's deductive methodology. In prima pars prudentia is brought into relation with the divine prudentia, and in prima secundae pars it is elaborated in the framework of general discussions of human actions and their purpose, free will, passions, habits, sin, etc.

\section{Divine prudentia}

Before considering prudentia as part of the human sphere, Aquinas considers it in relation to God, in two aspects: epistemological and moral. According to him, the most perfect knowledge lays in God and that is why he occupies the highest place when it comes to knowledge. God contains all perfection in himself, as perfect acts do in relation to the imperfect. In that sense, man has different kinds of knowledge according to the different objects that Divine knowledge has. He says:

Now man has different kinds of knowledge, according to the different objects of His knowledge. He has "intelligence" (intelligentia) as regards the knowledge of principles; he has "science" (scientia) as regards knowledge of conclusions; he has "wisdom" (sapientia) according as he knows the highest cause; he has "counsel" (consilium) or "prudence", according as he knows what is to be done. (ST I, q. 14, a. 1)

Aquinas speaks of the different kinds of knowledge in man in order to indicate that they exist in him in an imperfect way, while in God they exist in a perfect way, simply and in harmony. The mere fact that there is a division of knowledge indicates the existence of imperfection. Prudentia, like other human kinds of knowledge, exists in God as "a simple act of knowledge"; God knows what needs to be done, and just knowing His divine will fulfills that purpose.

Speaking of the moral aspect, Aquinas refers to Augustine: "the soul needs to follow something in order to give birth to virtue: this something is God: if we follow Him we shall live aright" (De Moribus Eccl. Vi, in ST I-II q. 61, a. 5). He believes that the exemplar of human virtue must pre-exist in God, just as the types of all things pre-exist. Virtue originally existed in God and therefore we can speak of the so-called "exemplar" virtues: 
in God the Divine Mind itself may be called prudence; while temperance is the turning of God's gaze on Himself, even as in us it is that which conforms the appetite to reason. God's fortitude is His unchangeableness; His justice is the observance of the Eternal Law in His works (ibid.)

According to Aquinas, those people who tend towards Divine similitude are adorned by the so-called "perfecting virtues". Thus prudentia, by contemplating the things of God, is attained by regarding earthly things as insignificant, and directs all thoughts of the soul to God alone; moderation, as far as nature allows, neglects the needs of the body; fortitude prevents the soul from being afraid to neglect the body and to ascend to the things of God; and justice consists in giving wholehearted consent to the soul to follow the path thus proposed. In addition to these, Aquinas defines the so-called "perfect virtues" belonging to those who have already attained the likeness of God; in this sense, prudentia is defined as a virtue that sees nothing but the Divine things.

Apart from their etymological similarity, providentia is conceptually closely related to prudentia. This relation is based on their tendency to direct things towards their end and therefore they can be appropriately attributed to God because he is the ultimate end of all things. Providentia actually represents the ratio of things by which things are properly ordered to move towards a certain end. The good in the order of created things is placed by God, which means that what is denoted as the ratio of the order of things to move toward a particular end lies in the mind of God. According to Steele, the connection between these two categories lies in the broader perspective of the general theological scheme used by Aquinas - exitus et reditus (all things come from God -exitus, and all things return to Him - reditus). This pattern, according to him, related to these two categories, refers to the category of bonum that exists intrinsically in creatures (Steele, s.a., 2). In creatures, and especially in man, good is found not only on the account of their substance as an intrinsic characteristic, but also because of their ordering to be directed to an end, especially to their ultimate end, and that is Divine goodness. According to Aquinas, this kind of ordering refers to providentia.

Aquinas adds that providentia is an important part of prudentia because prudentia focuses on two particularly important aspects: the remembrance of the past and understanding of the present. It is through these two aspects, the remembrance of the past and the understanding of the present, we gather how to provide for the future (ST I, q. 22, a. 1). According to Aquinas, two things belong to providentia: the type of the order of things foreordained towards and end, and the execution of that order, which is called government (ST I, q. 22, a. 3).

Aquinas goes on to analyze prudentia as a human virtue. "Now that we have treated of the exemplar, i.e. God, and of those things which came forth from the power of God in accordance with His will; it remains for us to treat of His image, i.e. man" (ST I-II, Prol.). In this exemplary connection lies Aquinas' 
intervention on Aristotle's treatment of prudentia, namely its transformation within Christian moral theology, especially through the concept of synderesis, elaborated later in this text.

\section{Prudentia}

Prudentia is one of the four cardinal virtues, along with justice, temperance, and fortitude. According to Aquinas, these virtues receive this status because they are general in comparison to other virtues which can be contained in them. For example, any virtue that causes good in reason's act of consideration can be called prudentia. They also receive cardinal status, unlike other virtues because of the importance to which they refer. Prudentia is the virtue that commands, justice is the virtue that is about due actions between equals, temperance is the virtue that suppresses desires for pleasures of touch, and fortitude is the virtue that strengthens one against the dangers of death. According to Aquinas, a virtue is not perfect if it is isolated from the others, and believes that prudentia cannot be acquired unless a virtuous person also acquires temperance, fortitude, and justice. Once one is acquired, the others are acquired too. But what is prudentia?

As a principle of human action that is immanent to man, not set externally, Aquinas, like Aristotle, defines prudentia as habitus, as a certain disposition present in the soul. It perfects intellectual power both in terms of its end and in terms of its actions aimed at achieving that end as a good. Prudentia is the leading virtue among the cardinal virtues because it refers to the perfection of reason, while others refer to certain appetites. Prudentia is rational in its essence, and others in terms of participation.

According to Aquinas, prudentia represents the due reason why certain actions should be performed. A condition for its performance is that the agent is properly directed towards the ends of the action to which he is disposed of according to his will. The rectitude of choice depends on the due end as well as something suitably ordained to that due end. The man is that thing suitably ordained to that end by a virtue that perfects the soul in the appetitive part. According to Aquinas, prudentia is the most necessary virtue for human life because a good life consists of doing good deeds. In order to do good deeds, it is important not only what an agent does and by what means, but also why he acts, namely whether it comes from a right choice or from passion and impulse.

This virtue is an intellectual virtue; it perfects reason and appropriately affects things that are ordained to the end, namely those that belong to the practical sphere. Identically to Aristotle, Aquinas placed prudentia among the intellectual virtues, but he differentiated prudentia from the others in what it refers to, namely moral virtues. Precisely because prudentia is responsible for good choices, moral virtue cannot be without it, while it can be without other intellectual virtues, such as wisdom, science, and art. Although it belongs to intellectual virtues, its significance does not lie in contemplation, but in the 
performance of the action as an act of will, which is in fact the end of practical reason. The good in the human soul, according to Aquinas, must be in accordance with reason, so the end of moral virtues must necessarily precede reason. In this sense, prudentia does not determine the purpose of moral virtues, but only regulates the means, a thesis with which Aquinas significantly converges with Aristotle. Thus, one of the properties of natural reason is to function as synderesis, as an innate human ability to recognize the eternal first principles of moral reasoning. The rule of prudentia consists in deciding how and by what means a reasonable measure of action will be achieved. In fact, the end of every moral virtue is to maintain the measure that is appropriate to that virtue, and that measure is achieved by the proper rule of prudentia.

Aquinas explicitly distinguishes prudentia from moral or practical knowledge. It is not scientia, but recta ratio, it is not right "knowledge", but right "reasoning". Although prudentia includes scientia, it should not be identified with knowledge of moral principles. He separates the aspect of knowledge of moral principles from the disposition to decide and act correctly. However, it is important for the person who possesses prudentia to know, at the same time, the universal first principles of reason, as well as the particulars to which these universal principles apply. Universal principles are either the first principles of human action which are instructions of natural law that can naturally be known by every human being or a set of practical knowledge. The essence of prudentia lies in the effective connection of universal principles and the specific situation, and not just the knowledge of one or the other side of this connection. In order to prove the thesis that prudentia is not scientia one turns to the thesis that prudentia can not be lost by forgetting because it acquires not only knowledge but also experience. Finally, prudentia is aimed at applying moral knowledge, namely, it is aimed towards action.

There are three actions of the reason that relate to human action: the first is the counsel, an act of inquiry; the second is the judgment of what has been discovered; and the third is the command, an act which consists in carrying out the action for what has been advised and judged. The first two actions belong to the speculative intellect, namely, the inquiry and the judgment, while the third belongs to the practical intellect which is ordained to action. According to Aquinas, it is clear that the main effect of things performed by man is that of command, and that all others are subordinate. According to Westberg, this threefold division is integral to the coherent Tomist philosophy of action. According to Aquinas, in order to realize moral virtue, there must be a good choice; this requires the agent to accept the right means, and this, in turn, would not be possible unless the reason is rightly deliberating, judging, and commanding. (Westberg, 191-192)

The virtue that perfects the command, namely, prudentia, occupies the highest place, while the secondary, and virtues that follow are: eustochia, which perfects counsel, as well as synesis and gnome which are part of prudentia and which refer to judgment. It is important for the realization of moral action to im- 
plement quickly what has been decided, and to make a decision slowly. Therefore, according to him, caution appropriately belongs to prudentia so as not to fall unconsciously under evil counsel.

Characteristic for Aquinas' prudentia is its connection to one of the cardinal theological virtues - charity. According to him, moral virtues cannot exist without charity, and this also applies to prudentia. Man's disposition towards his ultimate end is achieved through charity and therefore neither prudentia can be without charity, nor other moral virtues, because they cannot be without prudentia. Ultimately, prudentia is charity if understood as a mover of the reason to discern.

\section{Types of prudentia}

In terms of the degree of achievement of prudentia, Aquinas distinguishes three types (ST II-II q. 47, a. 13). The first type is a false prudentia that resembles the real one from which it borrows its name. The man who possesses this kind of false prudentia acts towards the attainment of an evil end or that end is apparently good. A "good thief" can be said to be a "prudent thief" because he skillfully uses various means to carry out a theft, but that does not mean that he possesses prudentia. This kind of prudentia is possessed by sinners. The second type of prudentia is true prudentia because it directs human actions towards a good end, but it is imperfect. This type directs the action towards a particular good end, such as becoming a good sailor or a merchant, and not towards achieving a good life as a whole. Also, this type of prudentia fails to carry out the main act of prudentia, namely, to give an effective command to act, despite the fact that the council is properly taken, and a good and valid judgment is formed. This type of prudentia is characteristic of good and of wicked people. The third kind of prudentia, is at the same time true and perfect: it takes appropriate counsel, makes appropriate judgments, and takes appropriate commands, taking into account the good of human life as a whole.

In terms of its end, Aquinas distinguishes three types of prudentia. (ST II-II q. 47, a. 11) Thus, there is one prudentia which refers to the individual good, the second type - "domestic prudentia" which refers to the common good of the home, and the third - "political prudentia" which refers to the common good of the state or the kingdom.

Examples of men who possess prudentia are a good way to get closer to the essence of prudentia. For Aristotle it was Pericles, the model of the ruler, while for Aquinas, the general, namely military command and generalship, are the models representing prudentia. He combines strategy with execution. The strategist must think, but also react quickly, know how to organize, communicate and implement the previously conceived plan. 


\section{Parts of prudentia}

Aquinas analyzes the parts of prudentia in such detail that he vividly captures the essence of prudentia. He considers the parts according to three criteria and therefore there are three types: integral, subjective, and potential. (ST II-II, q. 48, a. 1-4)

As integral parts of prudentia, Aquinas lists the following: memory, understanding, reasoning, docility, shrewdness, foresight, circumspection and caution. The first five refer to prudentia as a cognitive virtue, while the rest belong to commanding and applying knowledge in action.

Memory, according to Aquinas, is important when it comes to experience because experience is the result of memories. Prudentia needs experience because only through it the truth can be revealed in most cases. Aquinas does not attach an intellectual dimension to understanding, but a right estimate of a final principle that is taken as self-evident. Thus, he believes, it is said that the first principles of demonstration are understood. Every deduction arises from certain judgments which are taken as primary, and therefore every process of reasoning must arise from some kind of understanding. Furthermore, for prudential, particular cases of action are important which are of infinite variety and which a person could not know sufficiently. Therefore, according to Aquinas, achieving prudentia requires learning from others, especially older folks who have acquired an understanding of the ends in practical matters. Thus, in order to be ready to receive such teaching, one who aspires to prudentia must have the characteristic of docility. While docility is a disposition to acquire a right opinion of another, shrewdness is an apt disposition to make an independent right estimate. Aquinas refers to Aristotle, who sees shrewdness as "an easy and rapid conjecture in finding the middle term" (Poster. i, 9. In ST II-II, 48, a. 1). Aquinas associates reasoning with counseling because he sees it as research that is the work of reason. Foresight is a part of prudentia because it focuses on the future to which what is happening in the present should be directed. Circumspection, on the other hand, is important for prudentia, according to Aquinas, because an action that is in itself good and appropriate for the end should not become evil due to an inappropriate combination of circumstances. Finally, prudentia needs caution in order to pursue good, to avoid evil, and to distinguish one from the other, because very often the good is hindered by the evil, and the evil resembles the good.

According to Aquinas, it is inherent in prudentia to govern and command, and therefore when a certain kind of government can be seen in human actions, it must be considered that there is a special kind of prudentia. This refers to the subjective parts of prudentia that depend on whether it is self-government or government of a multitude. When it comes to governing a multitude, there are several types: military, domestic, regnative and political prudentia. If prudentia is taken in a broader sense, including speculative knowledge, then its parts may include dialectics (arrival at an opinion in terms of probable 
premises), rhetoric (using conjectures to induce suspicion or persuasion), and physics (acquisition of science through demonstration).

In the third group, the parts of prudentia belong to the virtues that are related to it and are directed to certain secondary actions, but they do not possess all the power of the main virtue. These are: good counsel, the part that concerns counseling; synesis, the part that concerns judgment in ordinary occurrences; and gnome, the part that concerns the judgment of things that are an exception to the law.

\section{Imprudentia}

The aspect of prudentia which refers to the intellect qua intellect is related to the search for truth in relation to the action. In this sense, explaining the possibility of error of the intellect is also a good basis for explaining the error of vice action. Aquinas enumerates many virtuous actions that refer to the violation of various aspects of prudentia. However, their explanation, although they are errors of practical reason, lies in the intellect in terms of will or passions.

Aquinas, speaking of the vices of prudentia, speaks not only of those vices which represent opposition or privation of prudentia, but also of those which bear a false resemblance to it, namely, which constitute an abuse of the things necessary to attain prudentia (ST II-II q. 53-55).

As privation, imprudentia represents a lack of prudentia, and according to Aquinas, such imprudentia is a sin. Imprudentia is considered to be the opposite of prudentia when the rules necessary for prudentia are violated, for example, if one does not accept counsel. The violation of the rule of "counsel" (to which eubolia refers), as imprudentiae correspond to "precipitation" and "temerity"; the violation of the rule of "judgment" (to which synesis and gnome refer) corresponds to "thoughtlessness"; and for violating the rule of "command" - "inconsistency" and "negligence". Also in opposition to prudentia are those imprudentiae that represent the deprivation of the parts of prudentia, but since these parts refer to the three kinds of actions of prudentia (counsel, reason, command), they can be reduced to the aforementioned imprudentiae. Thoughtlessness includes incautiousness and incircumspection; lack of memory, docility, or reason include precipitation; improvidence, lack of intelligence, and shrewdness include negligence and inconstancy. According to Aquinas, the perfection of prudentia and of every intellectual virtue consists in the abstraction of the sensory objects. Thus, as soon as the aforementioned imprudentiae include a defect in the attainment of prudentia and of practical reason, according to him, they derive mainly from lust.

The vices which are opposite to prudentia by the criterion of resemblance refer to the violation of the rule of the last end of life, namely, those supposed virtues which have at short-term ends. Here belong the so-called prudentiae of the flesh, which are aimed at an end that is seemingly good. Those prudentiae that are aimed at a certain end, good or evil, and that use means that are ficti- 
tious and counterfeit, belong to craftiness. Guile and fraud are associated with the practice of craftiness. These vices bear certain similarities with prudentia in the use of reason. According to Aquinas, the undue use of reason occurs mainly in the vices that are exercised in opposition to justice, the chief of which is covetousness. Thus, he concludes, these vices arise mainly from covetousness.

Although Aquinas does not list them as cases of imprudentia, the results of akrasia lead to similar results as imprudentiae. Aquinas considers them when dealing with the questions of sin when discussing the "twofold knowledge", knowledge of general principles and of individual cases (ST I-II, 77, a. 2). According to him, a defect of any of them can hinder the right action. A man may have a general knowledge that an action is wrong (ex. fornication), but he cannot recognize that an individual case of such action should not be performed. In this way, he explains how the will may not follow the knowledge of general principles. A man can have correct knowledge both on a general and on a particular level, but does not take them into account in actu, and therefore acts against his principles. Aquinas lists three ways in which the agent is hindered from putting his knowledge into action: firstly, because of distraction; secondly, because of the influence of passions as opposed to knowledge, and thirdly, through bodily transmutation (ex. sleep or drunkenness).

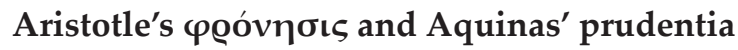

Prudentia in Aquinas' philosophy is directly modeled on Aristotle's

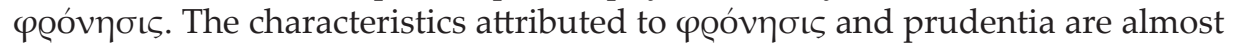
identical. The following can be mentioned as converging points in both concepts: the nature of prudentia as an intellectual virtue which belongs to practical reason and relates to action; the connection between prudentia and moral virtues; the distinction between prudentia and other intellectual virtues; the fact that prudentia refers to the universal and the particular; emphasizing the importance of deliberation, reasoning, and command in action, etc.

Undeniably, the theological character of Aquinas' prudentia because of which this concept acquires its own specificity makes the range of Aquinas'

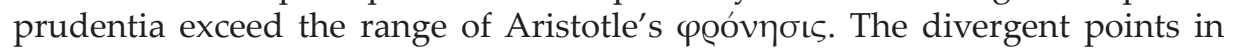
both concepts are: the relation of prudentia and the theological virtues given by God's grace, the relation between prudentia and divine providentia, the relation of prudentia with charity, and so on. The emphasis on the commanding role of prudentia, in place of the deliberative role, is to some extent in conflict with Aristotle. The main characteristic that Aquinas attributes to prudentia is the specific role he assigns to reason and will, as well as the conception of natural law and synderesis.

Various issues that arise from the comparison of these two concepts remain to be discussed. Of particular importance is the question of the purpose

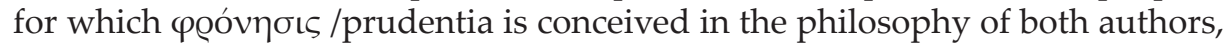
namely, whether in order to problematize human action or human action in re- 
lation to God. Aquinas retains Aristotle's issues, content, and even terminology, but some dilemmas remain: does Aquinas explicitly elaborate what is implicit in Aristotle? Is Aquinas' goal completely different from that of Aristotle? Does

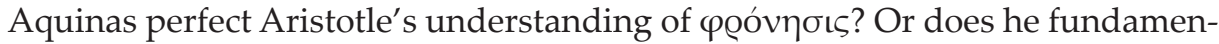

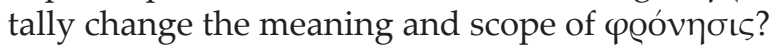

There are different assessments in the literature regarding the comparison of the two concepts. Rhonheimer believes that when Aquinas surpasses Aristotle, he complements Aristotle's understanding with premises necessary for it to become coherent (Rhonheimer, 1994). Vaccarezza believes that Aquinas' insistence on universality in ethics is in line with the views of Aristotle which are often interpreted from a position of moral particularism (Vaccarezza, 2012). Irwin accepts that Aquinas implicitly adopts the differentiation of universal and particular prudentia ${ }^{1}$, thus attributing a greater role to that of Aristotle, but in a rather Aristotelian way. When it comes to the relationship between prudentia and synderesis and natural law, he considers Aquinas to take a completely reductionist view (Irwin, 2007, 580-587). According to Bradley, Aquinas' thesis on synderesis transforms more than it develops Aristotle's philosophy (Bradley, 1997, 254). Jaffa, on the other hand, believes that Aristotle's goal is completely changed by Aquinas' prudentia being entirely dependent on self-evident practical principles (Jaffa, 1952). Gauthier thinks that Aquinas misinterprets Aristotle by depriving prudentia of the function of pursuing the ends of moral life (Gauthier \& Jolif, 1970). Finally, Roche concludes that Aquinas' notion of prudentia is not entirely Aristotelian, as is often assumed (Roche, 2005, 98).

One important discussion about the difference between the two concepts concerns the scope of $\varphi$ Qóvnoıs and prudentia, and most often refers to the question of the ends of $\varphi$ Qóvๆoıs/prudentia. This discussion leads to the idea

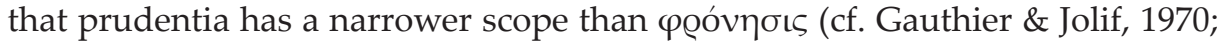

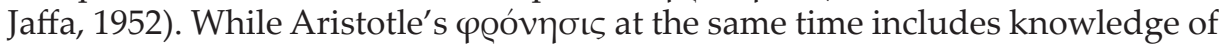
ends as well as means, Aquinas' end, since it is not in this life, cannot be known and is therefore not part of prudentia. Also, prudentia is limited to be in accordance with the first principles of natural law, thus deviating from Aristotle's

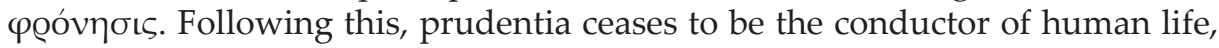
since the right actions depend more on the will or on God's grace. In this sense, prudentia can be considered to lack the full intellectual function of Aristotle's

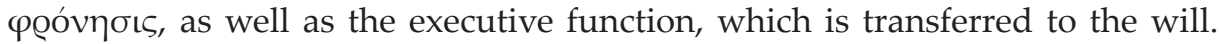

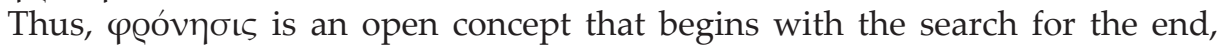
while prudentia is a limited concept within already developed principles whose

\footnotetext{
${ }^{1}$ According to Irwin, Aquinas recognizes the two roles of prudentia that are subject to the subsequent division explicitly given by Aquinas' successors. Universal prudentia takes us from the universal end to the particular virtuous end. It begins from the precept of acting in accordance with reason and reaches the conclusion, for example, to adjust our tendency to fear in order to become ready to face danger for the right reasons. Thus, we need to conclude that we need to cultivate bravery. Particular prudentia takes us from the particular virtuous end to the right actions. Bravery is assumed to be a virtue and it considers what would be brave to do in those circumstances. (Irwin, 2007, 582)
} 
function is only to choose and apply. According to Westberg, the disagreement between Aquinas and Aristotle does not refer to the nature of the deliberation (appropriate adaptation of the means to the end), but to their understanding of which ends should be chosen and how the particular action contained in the deliberation is carried out. The first aspect that refers to the ends is covered by the concept of natural law, and the second is by the concept of the will (Westberg, 30-31).

Undoubtedly, the question of synderesis is a key difference between the two concepts. In general, Aquinas retains the form of the moral act as in Aristotle, but wants to overcome the uncertainty of the moral syllogism left by Aristotle by adding natural law, natural disposition (habitus), or synderesis. Thus, the agent is not free to choose the great premise from experience or from tradition, which in Aquinas' case are not primary universal principles, but secondary, and prudentia becomes a mechanism by which particular actions are deduced from certain laws. In Aquinas, practical reason takes on a different dimension from that of being merely a kind of intellectual reasoning, developing a theory of the nature of moral good. Payer points to the concept of an application as crucial to the function of prudentia, a term which Aquinas believes he takes from the commentary of "Nicomachean Ethics" by Albert the Great. In fact, the term applicatio becomes a central concept in the analysis of prudentia. One of the basic principles of prudentia is the application, according to the syllogistic model, of the principles of practical intellect to the particular circumstances of human action (Payer, 1979, 67). He points out that some authors (cf. Deman, 1949) consider such an intervention in Aquinas' understanding of prudentia to be an invention and original addition to the development of this concept, but he argues that this intervention is largely made by Albert the Great and that he first developed a theory of prudentia which connects prudentia as a virtue with the first principles of natural law (ibid.). With this intervention by Aquinas, the flexibility of Aristotle's ethics has been replaced by more certain principles that determine moral actions. In this question, Nelson believes that Aquinas struggles with two traditions: the classical Aristotelian tradition of virtues and the Christianized Stoic tradition of natural law (Nelson, 1992, 99). Because of this conflict situation, Aquinas must also intervene in the understanding of prudentia. Westberg believes that it was impossible for Aquinas to maintain both freedom and truth at the same time and that he should have made a choice: either to emphasize the Aristotelian teleological element or to emphasize the absolute starting-points and significance of truth, but at the same time to lose some from Aristotle's freedom. (Westberg, 33-34) Aquinas apparently chose the latter. Although Aquinas still has some unanswered questions about the way in which deliberation takes place, one still gets the impression that in this respect things are much clearer than with Aristotle. 


\section{Conclusion}

Aquinas faces many challenges in conceiving prudentia and his moral theory in general. Westberg points out the following: clarification of the mutual functioning of reason and will; clear establishment of order in the process of action, namely, the model of action from intention to execution; demystification of practical syllogism as key to the decision-making process; and adapting Aristotle's ethics to the Christian teachings of sin, grace, the Holy Spirit, and theological virtues (Westberg, 2002, 13-14). The general impression is that Aquinas successfully handles many of these challenges, even better than Aristotle. The main component that allows Aquinas to overcome the great problems that arise in defining a concept that follows the hermeneutic cycle of the general and the individual is the addition of natural law. Precisely because of this elegant solution, the interpretation of prudentia in modern elaborations of virtue ethics, in certain circles, becomes paradigmatic. But the question remains how valuable it is to sacrifice freedom at the expense of certainty. 


\section{Користена дитература:}

Aquinas, T. St. Summa Theologica. https://www.ccel.org/ccel/aquinas/summa. html

Bradley, Denis J. M. (1997) Aquinas on the Twofold Human Good. Washington, D.C.: The Catholic University of America Press, 1997.

Celano, A. "Medieval Theories of Practical Reason." The Stanford Encyclopedia of Philosophy (Winter 2018 Edition), Edward N. Zalta (ed.).

$\mathrm{URL}=<$ https://plato.stanford.edu/archives/win2018/entries/practical-reason$\mathrm{med} / \mathrm{s}$.

Gauthier, R. A., J. Y. Jolif. (1970) Aristote: L'Éthique à Nicomaque. Louvain.

Irwin, T. (2007). The Development of Ethics - A Historical and Critical Study. Vol. I: From Socrates to the Reformation. Oxford: Oxford University Press.

Ordinatio. John Duns Scotus. The Ordinatio of Blessed John Duns Scotus.

https://www.aristotelophile.com/Books/Translations/Ordinatio\%20I.pdf (Accessed 25.12.2020)

Nelson, M. D. (1992) The Priority of Prudence: Virtue and Natural Law in Thomas Aquinas and the Implications for Modern Ethics. University Park: Pennsylvania State University Press.

Osborne, T. M. Jr. (2010). "Thomas and Scotus on Prudence Without all the Major Virtues: Imperfect or Merely Partial?" The Thomist: A Speculative Quarterly Review, Volume 74, Number 2, 165-188

Payer, P. J. (1979). "Prudence and the Principles of Natural Law: A Medieval Development" Speculum, Vol. 54, No. 1, 55-70

Rhonheimer, M. (1994). Praktische Vernunft und Vernünftigkeit der Praxis: Handlungstheorie bei Thomas von Aquin in ihrer Entstehung aus dem Problemkontext der aristotelischen Ethik. Berlin: Akademie Verlag.

Roche, D. (2005). Prudence in Aristotle and St. Thomas Aquinas. MA Thesis, Faculty of Philosophy, National University of Ireland, Maynooth.

Steele, A. M. (s.a). "On Prudence According to St. Thomas Aquinas." https:// www.academia.edu/20062509/On_Prudence_According_to_St_ Thomas_Aquinas

Vaccarezza, M. S. (2012). Le ragioni del contingente: La saggezza pratica tra Aristotele e Tommaso d'Aquino. Naples: Orthotes.

Westberg, D. (2002). Right Practical Reason: Aristotle, Action, and Prudence in Aquinas. Oxford: Clarendon Press. 
